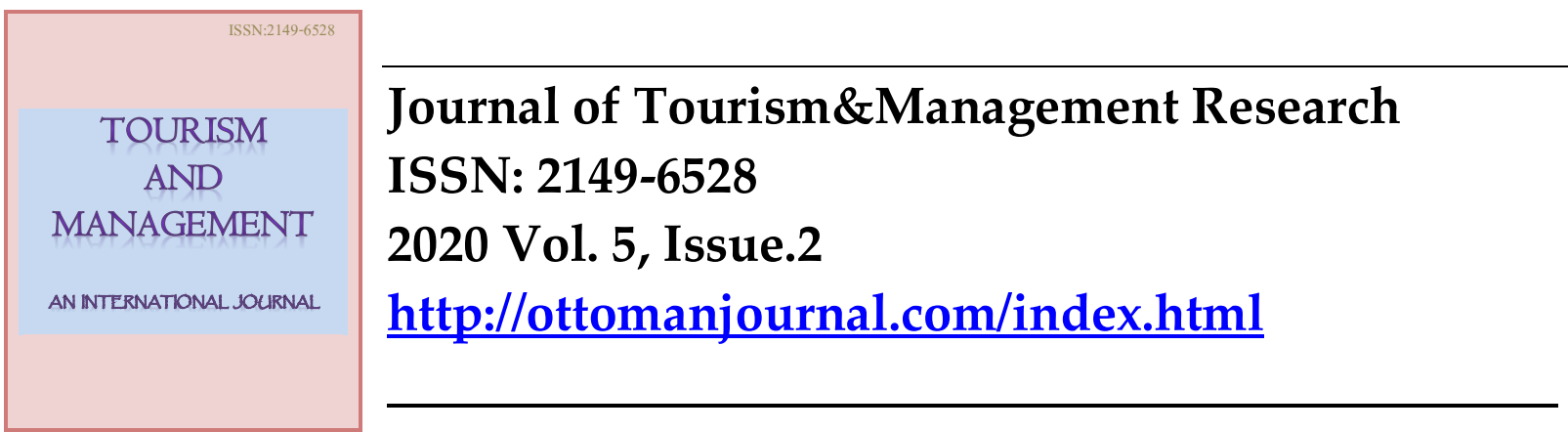

\title{
The Role of Constraints in Determining Domestic Tourism Participation Behaviour: A Comparison of the Perspectives of Domestic Tourism Participants and Non-Participants
}

\begin{abstract}
This study sought to examine the influence of constraints on domestic tourism participation behaviour in Nairobi County. Explanatory and descriptive designs were employed. The target population comprised of residents of Nairobi County aged above 18 years. Questionnaires were used to collect data from 337 domestic tourists drawn from five tourist sites, and 339 residents who had not participated in domestic tourism drawn from eight shopping malls. The findings from the independent t-test indicated that there was a significant difference in constraints between the two sets of respondents with the non-participating respondents displaying more constraints than the participating ones $(\mathrm{t}=-15.18, d f=674, p<0.001)$. In addition, linear regression analysis revealed that constraints significantly predicted participation behaviour for both the participating respondents $(\beta=-0.206, p<0.001)$ and nonparticipating respondents $(\beta=0.304, p<0.001)$. The study concluded that there was a need to differentiate strategies targeting the existing tourists and potential tourists since they were facing significantly different constraints. From a theoretical perspective, the study validates existing studies on effects of constraints on participation. From a practical point of view, the study identifies the nature of constraints affecting domestic tourism participants and nonparticipant and suggests the focus for marketing strategies for each group.
\end{abstract}

Keywords: Constraints, participants, non-participants, domestic tourism, participation behaviour.

JEL Codes: L83, M31, Z3

Submitted: 04/04/2020; Accepted:15/08/2020

Catherine Kifworo. Phd Student (Corresponding Author). School of Tourism, Hospitality and Events Management, Moi University, Kenya. Current Postal Address: PO Box 3900, 30100, Eldoret, Kenya.

Mobile Tel: +2540720953256

Email: ckifworo@gmail.com 
Moses Okello. Proffessor of Tourism and Wildlife Management. School of Field Studies. Center for Wildlife Management Studies, Kenya. Current Postal Address: PO Box Current Postal Address: 27743, 00506, Nairobi, Kenya. Mobile Tel: 0722598884

Email: mokello@fieldstudies.org

Isabella Mapelu, Phd. School of Tourism, Hospitality and Events Management, Moi University, Kenya. Current Postal Address: PO Box 3900, 30100, Eldoret, Kenya. Mobile Tel: +2540721225939

Email: immapelu@yahoo.com

\section{Introduction}

Domestic tourism is the key driver of the tourism sector globally as demonstrated by the fact that it accounted for $73 \%$ of total travel and Tourism spending in 2018 (World Travel Tourism Council, 2019). Top tourism destinations are often characterized by the presence of a strong and vibrant domestic tourism portfolio. According to UNWTO ranking, an analysis of the top five international tourism destinations (France, Spain, USA, China, and Italy) reveals that in each of these destinations, domestic tourism outstrips international tourism (UNWTO, 2019). Research from the South African domestic tourism strategy has further demonstrated that domestic tourism tends to play a major role in the sustainability of most successful tourism destinations (The National Department of Tourism South Africa, 2012). However, despite the fact that domestic tourism accounts for a significant proportion of the tourism industry, its uptake in developing countries is still lower than the global threshold where domestic tourism uptake is more than three times that of international tourism (UNWTO, 2018).

In East Africa, the segment remains largely untapped as the majority of East African residents have not visited prime tourist destinations or seen wildlife in their own countries (Okello \& Novelli, 2014). According to the Economic Survey 2019, domestic tourism in Kenya accounted for $52.1 \%$ of total bed nights $(4,489,800$ bed nights) in 2018 (Kenya National Bureau of Statistics, 2019; Tourism Research Institute, 2018). Though these statistics represent a remarkable growth compared to past years when international tourism flows were higher than domestic tourism, the status of domestic tourism in Kenya is still a point of concern. The performance is not only below the international standards but also below the country's targets which according to the third medium-term plan of the Vision 2030 was set at 6.5 million bed-nights annually (Government of Kenya, 2018). This state of affairs depicts a weak domestic segment that cannot adequately cushion the industry against the turbulence often experienced in the international market. There is, therefore need for research to identify barriers to participation in domestic tourism (Manono \& Rotich, 2013). These barriers also known as travel constraints, form a significant component of tourism literature as they not only inform planning but also the formulation of marketing strategies that facilitate participation in tourism.

Travel constraints have been defined as barriers that inhibit people's travel activities (Hung \& Petrick, 2010). They are the limitations and difficulties that prevent participation in leisure activities hence by extension participation in domestic tourism. Gassiot et al. (2018) conceptualized travel constraints as factors that can inhibit travel satisfaction, motivation, and needs. Constraints limit the formation of leisure preferences and prohibit participation and enjoyment of leisure often resulting in non-participation (Crawford \& Godbey, 1987). However, other scholars argue that constraints do not necessarily lead to non-participation in tourism, but can be negotiated to lead to participation (Kay \& Jackson, 1991; Shaw et al., 1991). Indeed as posited by (Kattiyapornpong \& Miller, 2009), there are significant levels of travel even among the most constrained groups as well as significant amounts of non-travel by the least constrained ones. 
Given the argument above, it is evident that domestic tourism participation behaviour comprises of both participation and non-participation, hence the need to consider the perspectives of both groups. This resonates with the sentiments by Nyaupane \& Andereck (2007), who opined that it is important to examine both participants and non-participants especially in terms of constraints affecting participation in domestic tourism. In this study, tourism participation behaviour is conceptualized through participation and non-participation. Notably, understanding the reasons for non- participation provides a fundamental basis for determining the significant constraints that a destination needs to negotiate in order to increase participation (Funk et al., 2009 ; Li et al., 2016; Park and Petrick, 2009). According to Li et al. (2015), the scarcity of current research on domestic tourism non-participation and the significance of non-tourists in the tourism business presents a gap, which in turn provides the focus for this study. This study, therefore seeks to contribute to this gap by establishing the relationship between constraints and domestic tourism participation behaviour for both participants and non-participants. It further seeks to compare the constraints faced by participants and those faced by non-participants. It is hoped that the study will yield information that will facilitate the formulation of strategies to retain participants and to convert non-participants who are considered to be potential tourists into active domestic tourists (participants).

\section{Literature Review}

\subsection{The Nature of Travel Constraints}

Research on constraints to participation emanated from leisure studies dating back to the early 1960s with the general assumption being that they led to non-participation (Hung and Petrick, 2012). Tourism studies have since picked up the concepts of constraints in the context of participation and non-participation. Various scholars have not only identified the constraints but also moved on to classify and evaluate the interrelationships between them and other factors including domestic tourism participation behaviour. As earlier stated, tourism participation behaviour comprises of both participation and non-participation in tourism.

Literature reveals a plethora of studies that have attempted to classify constraints. Jackson and Searle (1985) viewed constraints to travel as being either internal or external. Poria et al. (2009) categorized constraints into physical and social constraints. Freeman and Selmi (2009) classified constraints into physical, attitudinal, financial and communication barriers. Crawford et al. (1991)identified three types of constraints namely intrapersonal, interpersonal and structural constraints. Hua et al. (2013) expanded the categorization by Crawford et al. (1991) by adding cultural barriers hence forming intrapersonal, interpersonal, structural and cultural constraints.

Apart from categorization, early studies also concentrated on identifying the constraints to participation in leisure (Buchanan and Allen, 1985; McGuire, 1983). Most of these studies isolated constraints in the context of international travel with very few examining the domestic scenario (Nyaupane and Andereck, 2007). As stated by Li et al. (2015), the way constraints such as income, travel distance, time and language barriers affect participation in domestic tourism is quite different from how they affect international tourism hence the significance of separating the two. The section below explores constraints from both contexts.

From the international perspective, lack of money, poor health, time family support or interest were identified as primary constraints to travel by (Blazey, 1987). Tian et al. (1996) identified cost, time, the difficulty of access, repetition, product failings and lack of interest as main constraints to tourism participation. Nadirova and Jackson (2000) identified five broad constraints domains that limit participation in tourist activities namely; isolation (e.g. lack of safety, lack of transportation), Knowledge (e.g. lack of information), skills (e.g disabilities, discomfort in social settings), costs (e.g administration fees) and commitments (e.g lack of time). Pizam and Fleischer (2002) identified constraints amongst Israel senior citizens to be 
lack of leisure time, discretionary income and poor health. Time and cost were found to be the most widely experienced and challenging structural constraints according to (Hinch et al., 2005).

Goeldner and Ritchie (2011) identified six types of constraints to travel namely cost, time, health limitations, family stage, lack of interest and finally fear and safety. Lew et al. (2008) identified the following as constraints to travel: lack of free time, lack of disposable income, lack of information, need to stay home and care for the family, personal health/disability, crime concerns, civil unrest and wars, terrorism, disease concerns, personal phobias such as aerophobia, natural disasters, institutional barriers/legal restrictions and negative attitudes of the locals towards tourists. Other studies have identified socio-demographic factors as significant constraints to participation in tourism including age, income and life cycle (Kattiyapornpong \& Miller, 2009). Korstanje (2011) added to the fear and anxiety debate as a constraint to travelling. Pivac (2012) identified a lack of leisure time, cost, lack of finances and influence of season as barriers to participation in wine tourism.

Other studies have identified constraints facing tourists with disabilities. Freeman and Selmi (2009) compared constraints facing tourists with disabilities from Canada and France. Poria et al. (2009) analysed constraints faced by individuals with a disability in hotels. Hua et al. (2013) analysed constraints affecting participation in sports tourism by the physically disabled in Malaysia while Gassiot et al. (2018) analysed constraints affecting Spanish tourists with disabilities.

Moving to constraints specific to domestic tourism, Scheyvens (2007) identified lack of product diversification, hotels built to meet the needs of the international tourists and unaffordable accommodation as barriers to domestic tourism. Wang and Chen (2013) and Cai et al. (2002) isolated poor service, lack of product diversification, inefficient transport systems especially during peak hours, expensive accommodation with an international orientation as challenges facing China's domestic tourism. Magableh and Kharabsheh (2013) identified poor infrastructure, focus on inbound tourism, long distances to destinations, high entry fees, spending on external tourism, political disturbances, family size, lack of publicity/marketing/awareness, time, disposable income, direct transport and attractions as barriers to domestic tourism.

In Africa, constraints to domestic tourism have also been extensively identified by numerous studies. A study by Mazimhaka (2007) identified the following as hindrances to participation in domestic tourism in Rwanda; lack of tourism culture, insufficient information, financial limitations and lack of product diversification. Thapa (2012) identified lack of money, insufficient time, inaccessibility and unsuitable weather as constraints to domestic tourism. A study carried out in South Africa identified the following as constraints to domestic tourism; the perception that tourism was not affordable, lack of motivation to participate in tourism, lack of free time, poor travel culture including lack of saving for holiday culture, lack of knowledge of available affordable accommodation options, poor marketing strategies for domestic tourism, lack of tailor-made products suited to the domestic market, limited resources dedicated to development and promotion of domestic tourism (The National Department of Tourism South Africa, 2012). Kruger and Douglas (2015) further identified time, distance and affordability as the main constraints affecting black domestic tourists in South Africa. Lack of product variety, expensive tourism product aggravated by government policies that advocate for high value-low volume approach and lack of travel culture were identified as constraints to domestic tourism in Botswana (Morupisi and Mokgalo, 2017). Stone and Stone (2017) further applied the hierarchical model and established that intrapersonal constraints faced by domestic tourists in Botswana were lack of travel culture, the perception that tourism is for whites; interpersonal constraints were the shortage of affordable family accommodation while structural constraints included inaccessibility and lack of finances. 
Several studies have also identified constraints to domestic tourism in the Kenyan context. All the studies identified lack of disposable income and free time as a constraint. In addition, they identified the following; limited scope of tourist activities within most of the destination areas and limited travel information (Ndivo et al., 2012); lack of awareness and personal transport (Mutinda \& Mayaka, 2012); poor marketing to local people, unfamiliar food types in hotels, high cost of food and hospitality services within national parks (Okello et al., 2012); Lack of awareness, lack of hospitable treatment to local tourists by service providers, lack of travel cultures, negative perceptions that tourist destinations are for the rich and foreign (Manono and Rotich, 2013); lack of product diversification and safety concerns such as terrorism and political instability (Okello and Novelli, 2014); expensive products especially the accommodation component, lack of product diversification, international orientation of the industry hence neglecting the needs of the domestic traveller, perception that tourism is expensive, lack of own transport, lack of travel culture (Kihima, 2015).

In addition to these studies, the Kenya National Tourism Strategy 2013-2018 identified lack of an enabling environment and lack of knowledge of the potential products by Kenyans as major constraints to domestic tourism in the country (Government of Kenya, 2013). Despite the expansive studies done in identifying the constraints, there is an evident gap in studies that link constraints to participation and compare constraints as perceived by people who have participated in tourism to those who haven't especially in the Kenyan context. This study seeks to fill this gap by testing the following hypotheses:

$\boldsymbol{H}_{0}$ 1: There is no significant difference in tourism constraints between participants and nonparticipants of domestic tourism amongst residents of Nairobi County.

$\mathrm{H}_{0}$ 2: There is no relationship between tourism constraints and participation in domestic tourism in Nairobi County.

\subsection{Theoretical Framework}

As earlier stated, besides identifying constraints, other studies have moved a step further to categorize these constraints and then use models to evaluate the relationship between them and other factors .This study is anchored in the hierarchical constraint model by Crawford et al.(1991) as illustrated in figure 1. The model identifies three types of constraints that may inhibit an individual's desire to participate in tourism namely, intrapersonal, interpersonal and structural constraints. The constraints are thought to occur in a hierarchical manner with the intrapersonal ones being encountered first, followed by the interpersonal and then the structural ones coming last.

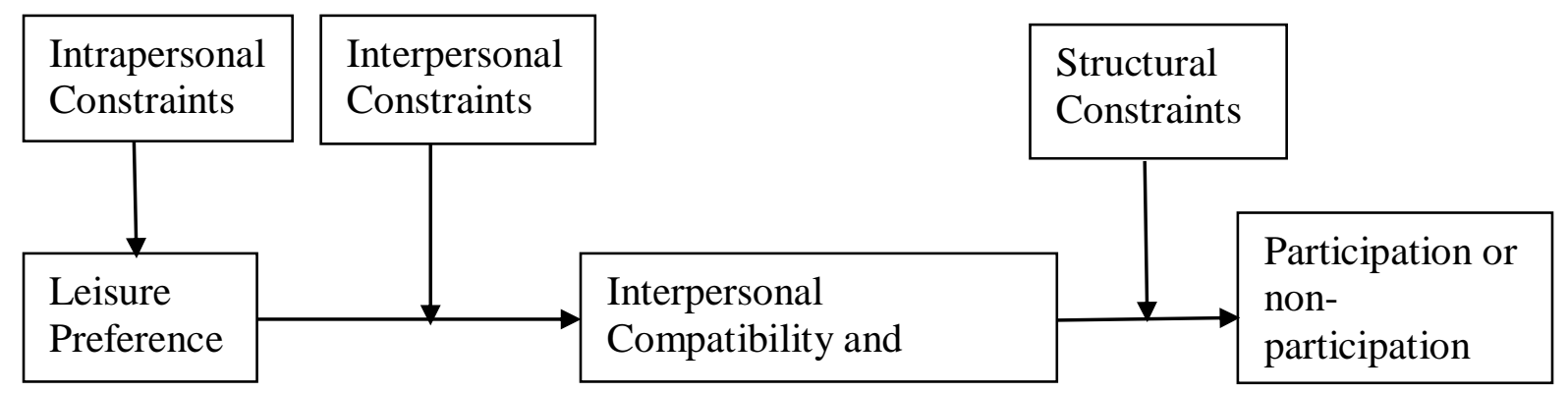

Figure 1: Hierarchical Model of Leisure Constraints.

Source: Crawford et al. (1991) 
Intrapersonal constraints are defined as individual psychological attributes that affect the development of leisure preferences leading to non-participation (Crawford \& Godbey, 1987). They include stress, fear, lack of interest, shyness, depression, anxiety, health, perceived selfskill and perceived appropriateness of various leisure activities. These constraints are relatively unstable and may change within a short period. They require more work to overcome them rather than regular place marketing e.g changing attitudes (Nyaupane and Andereck, 2007).

Interpersonal constraints, on the other hand, are social factors that emanate from social interactions and exchanges (Thapa, 2012). They occur as a result of interactions with family, friends, and acquaintances who may influence preferences and the final decision. They are also caused by the unavailability of other people thus preventing an individual from participating in activities requiring at least one partner or in which there is a strong preference for a co-participant (Nyaupane et al., 2004). It may also present in the form of a lack of interest from the significant others to participate in the leisure activity (Gilbert and Hudson, 2000). Interpersonal constraints interact with both preferences and participation and are likely to change across life stages hence depend on marital status, family size, and type of activity.

Structural constraints represent external factors intervening between preference for and participation in tourism activities. They are externally derived (Crawford and Godbey, 1987). They include lack of disposable income, lack of opportunity, season, climate, lack of free time and inaccessibility. Within structural constraints, Nyaupane and Andereck (2007) isolated three sub-constraints namely time, cost and place (e.g., accessibility and weather). Out of three, time and cost were perceived to be most constraining. In actual sense, some scholars such as Hinch and Higham (2011), have termed structural constraints as insurmountable making them non-negotiable.

Some studies have shown that the first constraints to be encountered and negotiated are the intrapersonal followed by the interpersonal and then lastly the structural ones (Kattiyapornpong \& Miller, 2009). These three types of constraints have different effects on participation in tourism (Figueiredo et al., 2012). Studies on domestic tourism have shown that out of the three types of constraints, structural constraints are the most predominant (Hinch et al., 2005; Kruger and Douglas, 2015; Okello et al., 2012; Pennington-Gray and Kerstetter, 2002; Schneider et al., 2011; Thapa, 2012). This is followed by the interpersonal and then intrapersonal constraints. According to Kruger and Douglas (2015), the most common structural constraint was financial while the most frequent amongst the interpersonal constraints was disinterest from reference groups such as family and friends. In most cases, disposable income is the single most important determinant of tourism demand (Okello et al., 2012). According to Li et al. (2015), a potential tourist will exit the decision-making process if these constraints are not negotiated. Participation is therefore shaped by either absence or negotiation of these three constraints (Gilbert and Hudson, 2000).

Various studies have gone further and tested the hierarchical model in various settings including (Alexandris and Carroll, 1997), (Pennington-Gray and Kerstetter, 2002), (Lai et al., 2013) and (Stone and Stone, 2017). Most have portrayed a negative relationship between constraints and tourism participation (Crawford et al., 1991; Li et al., 2015). This has however been refuted by other scholars who posit that when successfully negotiated, constraints stop having a negative effect on participation (Hubbard and Mannell, 2001; Jackson et al., 1993; Peterson and Lambert, 2015). The hierarchical model was therefore later modified to include the constraints negotiation concept that suggests that constraints can be negotiated to allow for tourism participation ((Hubbard and Mannell, 2001; Jackson et al., 1993). Scholars such as (Kruger and Douglas, 2015) further suggest that the negotiation process also occurs sequentially with intrapersonal constraints being negotiated first, followed by interpersonal and then lastly the structural constraints. Other studies have indicated that sometimes those with more constraints participated more in tourism while those with fewer constraints 
participated less (Hung and Petrick, 2012; Kattiyapornpong and Miller, 2009; Kay and Jackson, 1991; Shaw et al., 1991). Literature has therefore indicated that non-participation is not an absolute outcome of constraints Jackson et al.(1993) and that there is no simple positive or negative relationship existing between constraints and participation ( $\mathrm{Li}$ et al., 2015). This study seeks to contribute to this argument.

\subsection{Tourism Constraints and Participation}

A review of tourism literature reveals a number of studies that have compared constraints amongst non-participants and participants in tourism as illustrated in table 1 below.

Table 1: Studies on constraints from the perspective of tourism participation and nonparticipation.

\begin{tabular}{|l|l|l|}
\hline & AUTHOR & MAIN GAP COVERED \\
\hline $\mathbf{1}$ & Blazey (1987) & $\begin{array}{l}\text { Compared travel participants and non-participants aged over 55 } \\
\text { years and above- found significant differences in constraints and } \\
\text { demographic characteristics namely gender, age, health and } \\
\text { income }\end{array}$ \\
\hline $\mathbf{2}$ & $\begin{array}{l}\text { Alexandris and } \\
\text { Carrol (1997) }\end{array}$ & $\begin{array}{l}\text { Compared constraints to participation in sports amongst } \\
\text { participants and non-participants, found that non-participants were } \\
\text { more constrained especially by intrapersonal constraints }\end{array}$ \\
\hline 4 & $\begin{array}{l}\text { Gilbert and Hudson } \\
\text { (2000) }\end{array}$ & $\begin{array}{l}\text { Compared skiers and non-skiers - non-skiers experienced more } \\
\text { intrapersonal constraints, both groups experienced economic } \\
\text { factors and lack of time as a constraint. }\end{array}$ \\
\hline 5 & $\begin{array}{l}\text { Hung and Petrick, } \\
\text { (2012) }\end{array}$ & $\begin{array}{l}\text { Non-users of nature-based tourism were constrained by lack of } \\
\text { knowledge, distance and transportation while users were } \\
\text { constrained by previous visitation experience }\end{array}$ \\
\hline 6 & $\begin{array}{l}\text { Compared constraints amongst cruisers and non-cruisers, found } \\
\text { significant difference between the two groups with cruisers having } \\
\text { lesser constraints }\end{array}$ \\
\hline 7 & $\begin{array}{l}\text { Lampared constraints between Chinese outbound tourists and non- } \\
\text { tourists, found similarities especially in the intrapersonal and } \\
\text { structural constraints which were significant in both groups }\end{array}$ \\
\hline Li et al., (2016) & $\begin{array}{l}\text { Analysed reasons for non-participation in domestic tourism in } \\
\text { China, isolated intrapersonal and economic constraints as the most } \\
\text { difficult to negotiate by non-tourists } \\
\text { Analysed influence of constraints on non-participation in domestic } \\
\text { tourism, isolated economic and leisure time as main constraints }\end{array}$ \\
\hline
\end{tabular}

Early researchers such as Blazey (1987) established that there were significant differences in constraints between travellers and non-travellers of leisure. Others such as Alexandris and Carroll, (1997) argued that non-participants are more constrained from an intrapersonal dimension than the participating tourists hence rendering it more significant to participation than structural and interpersonal constraints. Gilbert and Hudson (2000) shared the same sentiments in their study that compared skiers and non- skiers thereby establishing that skiers are affected by structural constraints while non-skiers are affected by intrapersonal constraints. The study further established that under structural constraints, cost was the most significant factor. Similar sentiments were shared by Kerstetter et al. (2002) who found that non-users were most constrained by lack of knowledge which is an intrapersonal constraint. 
However, in this case, they were also constrained by distance and transport which are structural.

Recent studies have also lent their voice to the subject. A study by Hung and Petrick (2012) compared constraints across people participating and those not participating in cruise tourism. The participating respondents displayed fewer constraints, a higher level of travel motivation and the ability to negotiate through those constraints as compared to the nonparticipating ones. Lai et al. (2013) established that intrapersonal and structural constraints were significant to both participants and non-participants while interpersonal constraints were not. Li et al. (2015) also posited that there were different constraints between participants in domestic tourism and the non-participants. The intrapersonal and structural constraints were significantly different between the two groups while interpersonal constraints were the same. The non-participants were mainly constrained by economic challenges and intrapersonal constraints such as attitude and health. The participants were less discouraged by intrapersonal constraints and more hindered by structural constraints. A similar study by Li et al. (2016) also compared constraints amongst participants and non-participants in domestic tourism. Contrary to findings by $\mathrm{Li}$ et al. (2015), intrapersonal constraints did not play a major role. The participants were constrained mainly by interpersonal constraints and structural constraints in the form of destination factors. The non-participants were constrained by structural barriers in the form of economic factors and leisure time.

Stone \& Stone (2017) established that both the participating and non-participating respondents faced similar intrapersonal, interpersonal and structural constraints. However, there were significant differences in two areas. One, the non-participants did not perceive some activities such as viewing wildlife to be tourism since they were similar to what they encountered on a day to day basis. Secondly, they also cited lack of family commitment and the inability of families to afford tourism. These represented intrapersonal and interpersonal factors respectively. The above studies extensively identify constraints of tourism, establish the relationship between these barriers and tourism participation behaviour and proceed further to compare tourists and non-tourists. However, the studies are context-specific and do not address the Kenyan situation. Some of the studies located in the African setting are purely qualitative hence the need for a quantitative study to validate the findings.

\section{Methodology}

The study used descriptive and explanatory research designs. The target population comprised of both domestic tourists and non-tourists aged over 18 years drawn from Nairobi County. Systematic random sampling was used to select 337 domestic tourists within in five tourist sites namely Nairobi National park, Giraffe Centre, Nairobi Safari Walk, Animal Orphanage and the National Museum of Kenya. The on-site survey was deemed fit for this study as recommended by (Chen and Funk, 2010). The differentiated entrance rates charged at the destinations were used to single out the domestic tourists from the international ones.

Multistage sampling was used to select 339 non-participating respondents from eight shopping malls drawn from the same constituencies that house the tourist sites listed above. Nairobi County is made up of 17 constituencies and 85 wards (County Government of Nairobi, 2014). A three-stage approach involved selecting the constituencies, then wards and finally the shopping centres. Stage one of sampling involved purposively selecting the constituencies that housed the tourism destination sites picked for the participating domestic tourists. This was deemed critical in ensuring a level playing ground for comparing participants and non-participants of domestic tourism. This resulted in two constituencies namely Lang'ata and Westlands. These two had a combined number of 10 wards which was too large for consideration. In order to attain a manageable sample, the second stage of sampling was then applied to these wards using the $30 \%$ sample selection threshold by Mugenda and Mugenda (2003) to yield a sample of four. Each of the 10 wards was allocated 
numbers after which a computer was used to randomly select four wards namely Karen, Mugumoini, Parklands/Highridge, and Kangemi. Since the study area was still too wide, the third stage of sampling was applied to the shopping centres found within the four wards to yield the final sampling unit.

In every ward, all the shopping centres were categorized into two lists, one comprising of upmarket shopping centres and the other one for modest ones. This was deliberately done to capture respondents from diverse economic backgrounds. A computer was then used to randomly pick two shopping centres from each ward, one from the upmarket and another from the modest range, making a total of 8 shopping centres that formed the sites for the actual survey. This technique is similar to that used by Mutinda and Mayaka (2012), and Li et al. (2015) in their studies on domestic tourism in Kenya and China respectively.

The actual survey at the shopping centres was conducted in the form of a street intercept as suggested by Veal (2017) who proposed the method as an appropriate technique for conducting tourism surveys at malls, shopping centres or on busy streets. The respondents were intercepted either as they got in or left the shopping centres, with permission from the management and security of the establishments. An elimination question was posed to the respondents at the start of the process in order to establish eligibility for inclusion in the study. All those who had not participated in domestic tourism were included in the study till the quota for the site was achieved. Deliberate efforts were also made to obtain the views of both genders by approaching both males and females within each site.

The study used a structured questionnaire to collect data. The respondents rated the items in terms of their likelihood to hinder participation in domestic tourism using a 5-point Likert scale ranging from 1 to 5 where 1 was very unlikely, 2 was unlikely, 3 was fairly unlikely, 4 was likely while 5 was most likely. Descriptive statistics in the form of means and standard error were used to summarize data and display the general trends. Inferential analyses were carried out to test hypotheses at the level of $\alpha=0.05$. Prior to the test, factor analysis carried out revealed a Cronbach Alpha value of 0.919 hence assuring reliability. The independent $\mathrm{t}-$ test was used to compare constraints between tourists and non-tourists, hence testing the hypothesis on the significant difference between the two groups. Similarly, linear regression was used to predict the influence of constraints on domestic tourism participation behaviour hence test the relationship between the two variables. The regression formulae employed was as follows:

$y=\beta 0+\beta 1 x 1+\varepsilon$, Where:

$\mathrm{y}=$ Participation Behaviour

$\beta 0=$ Constant or intercept

$\beta 1$ - Coefficient of Regression

$x 1=$ Constraint

$\varepsilon=$ Error

\section{Results}

\subsection{Descriptive Statistics}

In order to summarize data and display the general trends, the study computed means and standard error for structural, interpersonal and intrapersonal constraints. The study findings indicated that structural constraints differed across the two group as indicated in table 2. For the participating respondents, majority rated lack of free time as the most constraining barrier (mean= 3.53; SE=0.075), followed by lack of income (mean= 3.15; $\mathrm{SE}=0.078)$ and accessibility of destinations (mean $=3.08 ; \mathrm{SE}=0.083)$. The least constraining barriers were overcrowded destinations (mean $=2.55 ; \mathrm{SE}=0.082$ ), safety and security concerns (mean= 2.51; $\mathrm{SE}=0.079$ ), better options abroad (mean= 2.45; $\mathrm{SE}=0.084)$. In the contrary, majority of the non-participating respondents rated lack of variety of activities at destinations (mean= 4.51; $\mathrm{SE}=0.045)$ and lack of disposable income (mean= 4.51; $\mathrm{SE}=0.034)$ as the most likely 
constraints, followed by lack of free time (mean= 4.04; SE= 0.064). The least likely constraints were safety and security concerns (mean=2.81; $\mathrm{SE}=0.075)$, better options abroad (mean= 2.64; $\mathrm{SE}=0.067)$, and overcrowded destinations (mean= 2.39; $\mathrm{SE}=0.068)$. (see table 2).

Table 2: Structural constraints to domestic tourism participation.

\begin{tabular}{|l|l|l|l|l|l|}
\hline \multirow{3}{*}{ Preferences Attractions } & $\begin{array}{l}\text { Nature of } \\
\text { Respondents }\end{array}$ & Mean & $\begin{array}{l}\text { Std. } \\
\text { Error }\end{array}$ & Skewness & Kurtosis \\
\hline Constrained by Safety Concerns & Participants & 2.51 & 0.079 & 0.493 & -1.078 \\
\cline { 2 - 6 } & Non- Participants & 2.81 & 0.075 & 0.173 & -1.015 \\
\hline \multirow{3}{*}{ Constrained by Lack of Income } & Participants & 3.15 & 0.078 & -0.176 & -1.248 \\
\cline { 2 - 6 } & Non- Participants & 4.51 & 0.034 & -0.994 & 0.284 \\
\hline \multirow{2}{*}{$\begin{array}{l}\text { Constrained by Poor Quality } \\
\text { Services/Facilities }\end{array}$} & Participants & 3.05 & 0.079 & -0.099 & -1.354 \\
\cline { 2 - 6 } $\begin{array}{l}\text { Constrained by Lack of Variety of } \\
\text { Activities }\end{array}$ & Non- Participants & 3.98 & 0.050 & -0.713 & -0.239 \\
\cline { 2 - 6 } & Participants & 2.99 & 0.086 & 0.027 & -1.538 \\
\cline { 2 - 6 } Constrained by Lack of Free Time & Non- Participants & 4.51 & 0.045 & -1.231 & -0.324 \\
\cline { 2 - 6 } & Norticipants & 3.53 & 0.075 & -0.603 & -0.847 \\
\hline \multirow{2}{*}{$\begin{array}{l}\text { Constrained by Accessibility to } \\
\text { Destination }\end{array}$} & Participants & 3.08 & 0.083 & -0.029 & -1.553 \\
\cline { 2 - 6 } $\begin{array}{l}\text { Constrained by Weather } \\
\text { Conditions }\end{array}$ & Non- Participants & 3.90 & 0.068 & 0.664 & -1.249 \\
\hline \multirow{2}{*}{$\begin{array}{l}\text { Constrained by Better Options } \\
\text { Abroad }\end{array}$} & Participants & 2.72 & 0.082 & 0.300 & -1.333 \\
\cline { 2 - 6 } & Non- Participants & 3.01 & 0.065 & 0.135 & -0.613 \\
\hline \multirow{2}{*}{$\begin{array}{l}\text { Constrained by Overcrowded } \\
\text { Destinations }\end{array}$} & Participants & 2.45 & 0.084 & 0.572 & -1.194 \\
\cline { 2 - 6 } & Non- Participants & 2.64 & 0.067 & 0.724 & -0.298 \\
\cline { 2 - 6 } & Participants & 2.55 & 0.082 & 0.434 & -1.265 \\
\hline \multirow{2}{*}{} & Non- Participants & 2.39 & 0.068 & 0.993 & -0.118 \\
\hline
\end{tabular}

The results of the analysis showed that the most constraining interpersonal factor amongst participating respondents was family commitments (mean $=3.17 ; \mathrm{SE}=0.080$ ), followed by lack of family-oriented activities (mean $=2.94 ; \mathrm{SE}=0.084)$, and then lack of travel companion (mean= 2.74; $\mathrm{SE}=0.078$ ). For the non-participating respondents, majority felt constrained by lack of family-oriented activities (mean $=4.22 ; \mathrm{SE}=0.046)$ followed by family commitments $($ mean $=4.08 ; \mathrm{SE}=1.047)$ and then lastly by lack of travel companion (mean $=4.05 ; \mathrm{SE}=0.67)$ (see table 3).

Table 3: Interpersonal constraints to participation in domestic tourism.

\begin{tabular}{|l|l|l|l|l|l|}
\hline \multirow{3}{*}{ Preferences Attractions } & $\begin{array}{l}\text { Nature of } \\
\text { Respondents }\end{array}$ & Mean & Std. Error & Skewness & Kurtosis \\
\hline $\begin{array}{l}\text { Constrained by Lack of } \\
\text { Family-Oriented Activities }\end{array}$ & Participants & 2.94 & 0.084 & -0.009 & -1.469 \\
\cline { 2 - 6 } & Non- Participants & 4.22 & 0.046 & -1.599 & 3.810 \\
\hline $\begin{array}{l}\text { Constrained by Lack of Travel } \\
\text { Companion }\end{array}$ & Participants & 2.74 & 0.078 & 0.179 & -1.306 \\
\cline { 2 - 6 } & Non- Participants & 4.05 & 0.067 & -1.079 & -0.267 \\
\hline $\begin{array}{l}\text { Constrained by Family } \\
\text { Commitments }\end{array}$ & Participants & 3.17 & 0.080 & -0.267 & -1.267 \\
\cline { 2 - 6 } & Non- Participants & 4.08 & 0.057 & -0.735 & -0.792 \\
\hline
\end{tabular}

For the intrapersonal constraints, both the participating and non-participating respondents rated lack of personal transport, lack of travel culture, lack of knowledge of where to go and the perception that tourism is for others as the most constraining factors to participation in domestic tourism. The magnitude however differed with non-participating respondents registering stronger constraints than the participating ones as shown in table 4. Participating respondents rated lack of personal transport (mean $=3.42 ; \mathrm{SD}=0.083$ ), followed by lack of a travel culture $($ mean $=2.65 ; \mathrm{SE}=0.079)$, lack of knowledge of where to go (mean=2.64; $\mathrm{SE}=$ 
0.076) and perception that tourism is for others (mean= 2.58; $\mathrm{SE}=0.080$ ). The least constraining factors were poor health (mean= 2.39; $\mathrm{SE}=0.087)$ and disability (mean= 1.90; $\mathrm{SE}=0.081$ ). The non-participating respondents cited lack of transport (mean= 4.45; $\mathrm{SE}=$ 0.054 ), followed by lack of travel culture (mean= 4.42; $\mathrm{SE}=0.049)$, lack of knowledge of where to go $($ mean $=4.41 ; \mathrm{SE}=0.054)$, perception that tourism is for others (mean=4.26; $\mathrm{SE}=$ 0.049 ). The least constraining factors were previous bad experiences (mean $=2.35$; $\mathrm{SE}=$ $0.076)$, disability (mean=2.19; $\mathrm{SE}=0.074)$.

Table 4: Intrapersonal constraints to participation in domestic tourism.

\begin{tabular}{|c|c|c|c|c|c|}
\hline Preferences Attractions & $\begin{array}{l}\text { Nature of } \\
\text { Respondents }\end{array}$ & Mean & $\begin{array}{l}\text { Std. } \\
\text { Error }\end{array}$ & Skewness & Kurtosis \\
\hline \multirow{2}{*}{$\begin{array}{l}\text { Constrained by Perception That } \\
\text { Tourism is for Others }\end{array}$} & Participants & 2.58 & 0.080 & 0.414 & -1.206 \\
\hline & Non- Participants & 4.26 & 0.049 & -0.535 & -1.553 \\
\hline \multirow{2}{*}{$\begin{array}{l}\text { Constrained by Previous Bad } \\
\text { Experiences }\end{array}$} & Participants & 2.52 & 0.078 & 0.430 & -1.129 \\
\hline & Non- Participants & 2.35 & 0.076 & 0.586 & -0.949 \\
\hline \multirow{2}{*}{$\begin{array}{l}\text { Constrained by Lack of Travel } \\
\text { Culture }\end{array}$} & Participants & 2.65 & 0.079 & 0.351 & -1.192 \\
\hline & Non- Participants & 4.42 & 0.049 & -1.206 & 0.020 \\
\hline \multirow{2}{*}{$\begin{array}{l}\text { Constrained by Fear of the } \\
\text { Unknown }\end{array}$} & Participants & 2.53 & 0.081 & 0.478 & -1.148 \\
\hline & Non-Participants & 3.73 & 0.064 & -0.592 & -0.804 \\
\hline \multirow{2}{*}{$\begin{array}{l}\text { Constrained by Lack of Personal } \\
\text { Transport }\end{array}$} & Participants & 3.42 & 0.083 & 0.414 & -1.285 \\
\hline & Non- Participants & 4.45 & 0.054 & -1.754 & 2.400 \\
\hline \multirow{2}{*}{$\begin{array}{l}\text { Constrained by Lack of } \\
\text { Knowledge on Where to Go }\end{array}$} & Participants & 2.64 & 0.076 & 0.305 & -1.119 \\
\hline & Non- Participants & 4.41 & 0.054 & -1.651 & 1.417 \\
\hline \multirow[t]{2}{*}{ Constrained by Poor Health } & Participants & 2.39 & 0.087 & -0.550 & -0.728 \\
\hline & Non- Participants & 3.37 & 0.074 & 1.776 & 3.728 \\
\hline \multirow[t]{2}{*}{ Constrained by Disability } & Participants & 1.90 & 0.081 & 0.996 & -0.302 \\
\hline & Non- Participants & 2.19 & 0.074 & 0.668 & -0.994 \\
\hline
\end{tabular}

\subsection{Inferential Analysis}

The findings from the independent t-test as shown in table 5 revealed that there was a significant difference in constraints between the two groups of respondents $(\mathrm{t}=-15.182, d f=$ $674, p<0.01$ ), with the non- participating respondents (mean=3.67; $\mathrm{SE}=0.037$ ) registering more constraints than the participating ones (mean=2.78; $\mathrm{SE}=0.047$ ). The study, therefore, rejected the null hypothesis and concluded that there was a significant difference in constraints between participants and non-participants of domestic tourism amongst residents of Nairobi County.

Table 5: Mean differences in constraints for domestic tourism.

\begin{tabular}{|l|l|l|l|l|l|l|}
\hline & $\begin{array}{l}\text { Mean } \\
\text { Participating }\end{array}$ & $\begin{array}{l}\text { Mean Non- } \\
\text { Participating }\end{array}$ & $\begin{array}{l}\text { Std Error } \\
\text { Mean } \\
\text { Participating }\end{array}$ & $\begin{array}{l}\text { Std Error } \\
\text { Mean Non- } \\
\text { Participating }\end{array}$ & $\begin{array}{l}\text { T } \\
\text { Statistic }\end{array}$ & $\begin{array}{l}\text { P value } \\
\text { sig.2- } \\
\text { tailed }\end{array}$ \\
\hline Constraints & 2.78 & 3.67 & 0.047 & 0.037 & -15.182 & 0.000 \\
\hline
\end{tabular}

The findings of the t-test performed on individual variables as shown in table 6 revealed that majority of the variables scored significant differences in constraints between the participants and the non-participants. Only 3 out of 22 variables were not significantly different for the two groups. These constraints were better options abroad, previous bad experiences and overcrowded destinations. Therefore, in general, the results suggest that the participating respondents possessed significantly different constraints from the nonparticipating respondents. 
Table 6: Mean difference between the constraints facing respondents participating and those not participating in domestic tourism.

\begin{tabular}{|c|c|c|c|c|c|c|}
\hline Constraint & $\begin{array}{l}\text { Mean } \\
\text { Participating }\end{array}$ & $\begin{array}{l}\text { Mean Non- } \\
\text { Participating }\end{array}$ & $\begin{array}{l}\text { Std Error } \\
\text { Mean } \\
\text { Participating }\end{array}$ & $\begin{array}{l}\text { Std Error } \\
\text { Mean Non- } \\
\text { Participating }\end{array}$ & $\begin{array}{l}\text { T } \\
\text { Statistic }\end{array}$ & $\begin{array}{l}P \text { value } \\
\text { sig. } 2 \text { tailed }\end{array}$ \\
\hline Lack of free time & 3.53 & 4.04 & 0.075 & 0.064 & -5.179 & 0.000 \\
\hline $\begin{array}{l}\text { Lack of travel } \\
\text { companion }\end{array}$ & 2.74 & 4.05 & 0.078 & 0.067 & 12.751 & 0.000 \\
\hline $\begin{array}{l}\text { Family } \\
\text { commitments }\end{array}$ & 3.17 & 4.08 & 0.080 & 0.057 & 9.282 & 0.000 \\
\hline Poor health & 2.39 & 3.37 & 0.087 & 0.074 & 8.543 & 0.000 \\
\hline $\begin{array}{l}\text { Lack of } \\
\text { knowledge of } \\
\text { where to go }\end{array}$ & 2.64 & 4.41 & 0.076 & 0.054 & 18.931 & 0.000 \\
\hline Safety concerns & 2.51 & 2.81 & 0.079 & 0.075 & 2.765 & 0.006 \\
\hline Lack of income & 3.15 & 4.51 & 0.078 & 0.034 & 16.072 & 0.000 \\
\hline $\begin{array}{l}\text { Poor quality } \\
\text { services/facilities }\end{array}$ & 3.05 & 3.98 & 0.079 & 0.050 & 9.903 & 0.000 \\
\hline $\begin{array}{l}\text { Lack of variety of } \\
\text { activities }\end{array}$ & 2.99 & 4.51 & 0.086 & 0.045 & 15.67 & 0.000 \\
\hline $\begin{array}{l}\text { Lack family- } \\
\text { oriented activities }\end{array}$ & 2.94 & 4.22 & 0.084 & 0.046 & 13.339 & 0.000 \\
\hline $\begin{array}{l}\text { Lack of personal } \\
\text { transport }\end{array}$ & 3.42 & 4.45 & 0.083 & 0.054 & 10.503 & 0.000 \\
\hline $\begin{array}{l}\text { Perception that } \\
\text { tourism is for } \\
\text { others }\end{array}$ & 2.58 & 4.26 & 0.080 & 0.049 & 17.982 & 0.000 \\
\hline $\begin{array}{l}\text { Accessibility to } \\
\text { destination }\end{array}$ & 3.08 & 3.90 & 0.083 & 0.068 & 7.644 & 0.000 \\
\hline $\begin{array}{l}\text { Lack of travel } \\
\text { culture }\end{array}$ & 2.65 & 4.42 & 0.079 & 0.049 & 19.071 & 0.000 \\
\hline $\begin{array}{l}\text { Fear of the } \\
\text { unknown }\end{array}$ & 2.53 & 3.73 & 0.081 & 0.064 & 11.633 & 0.000 \\
\hline $\begin{array}{l}\text { Weather } \\
\text { conditions }\end{array}$ & 2.72 & 3.01 & 0.082 & 0.065 & 2.778 & 0.006 \\
\hline $\begin{array}{l}\text { Better options } \\
\text { abroad }\end{array}$ & 2.45 & 2.64 & 0.084 & 0.067 & 1.787 & 0.074 \\
\hline $\begin{array}{l}\text { Previous bad } \\
\text { experiences }\end{array}$ & 2.52 & 2.35 & 0.078 & 0.076 & 1.629 & 0.104 \\
\hline $\begin{array}{l}\text { Overcrowded } \\
\text { destinations }\end{array}$ & 2.55 & 2.39 & 0.082 & 0.068 & 1.557 & 0.120 \\
\hline Disability & 1.90 & 2.19 & 0.081 & 0.074 & 2.726 & 0.007 \\
\hline
\end{tabular}

The results from the linear regression analysis revealed that constraints significantly predicted domestic tourism participation behaviour for both participating $(\beta=0.206, p<0.001)$ and non-participating respondents $(\beta=0.304, p<0.001)$. The study, therefore, rejected the null hypothesis $\left(\mathrm{H}_{0} 2\right)$ to conclude that there was a significant relationship between constraints and domestic tourism participation behaviour for both participants and non-participants. Additionally, the analysis revealed that there was a negative and significant relationship between constraints and participation $(B=-.247 ; p<0.001 ; t=3.973)$ for the participating respondents. This infers that an increase by one unit in constraints leads to a 0.247 decrease in participation in domestic tourism. The results further indicate that there is a positive and significant relationship between constraints and domestic tourism participation behaviour $(B=$ $.173 ; p<0.001 ; t=4.957)$ for the non-participating respondents. Thus, an increase by one unit in constraints leads to a 0.173 increase in non-participation in domestic tourism. 
Based on the results, the model summary for the participating respondents was: $\mathrm{Y}=1.200-0.247 \mathrm{X}_{1}+0.169$.

While that for the non-participating respondents was: $\mathrm{Y}=2.024+0.173 \mathrm{X}_{1}+0.063$.

Table 7: Linear Regression analysis results.

\begin{tabular}{|c|c|c|c|c|c|c|c|c|}
\hline \multirow[t]{2}{*}{$\begin{array}{l}\text { Nature of } \\
\text { respondents }\end{array}$} & \multirow[t]{2}{*}{ Model } & \multicolumn{2}{|c|}{$\begin{array}{l}\text { Unstandardized } \\
\text { Coefficients }\end{array}$} & \multirow{2}{*}{\begin{tabular}{|c|}
$\begin{array}{c}\text { Standardized } \\
\text { Coefficients }\end{array}$ \\
Beta
\end{tabular}} & \multirow[t]{2}{*}{$\mathbf{t}$} & \multirow[t]{2}{*}{ Sig. } & \multicolumn{2}{|c|}{ Collinearity Statistics } \\
\hline & & B & $\begin{array}{c}\text { Std. } \\
\text { Error }\end{array}$ & & & & Tolerance & VIF \\
\hline \multirow{2}{*}{ Participant } & (Constant) & 1.200 & .169 & & 7.108 & .000 & & \\
\hline & Constraints & -.247 & .062 & .206 & 3.973 & .000 & .954 & 1.049 \\
\hline \multirow{2}{*}{ Non-Participant } & (Constant) & 2.024 & .063 & & 32.309 & .000 & & \\
\hline & Constraints & .173 & .035 & .304 & 4.957 & .000 & .710 & 1.408 \\
\hline
\end{tabular}

\section{Conclusion, Implications, and Limitations}

It is evident from the study that both participants and non-participants feel constrained hence supporting the view that constraints do not necessarily lead to non-participation (Hung \& Petrick, 2012; Kattiyapornpong \& Miller, 2009; Li et al., 2015). They nonetheless affect participation behaviour by reducing participation for the current tourists and increasing the likelihood of non-participation for the non-tourists. The results further confirmed previous findings by Gilbert and Hudson (2000), and Li et al. (2016) that cited lack of free time and income as main constraints to participating in tourism. Notably, in both instances, income did not rate as the number one overall constraint, but rather came second after lack of time for the participating respondents and lack of product variety for the non-participating ones. This is contrary to Okello et al. (2012) who postulated that disposable income was the single most important determinant of tourism demand. Thus, more research is required to ascertain other determinants of domestic tourism participation beyond income and constraints in general that strongly influence participation in domestic tourism.

Additionally, the study findings indicate that the constraints facing participants in domestic tourism significantly differ from those facing the non-participants. These results concur with findings by (Hung and Petrick, 2010; Li et al., 2015; Li et al., 2016). Additionally, contrary to what was posited by Kattiyapornpong and Miller (2009), the non-participants were more constrained than the participants. Specifically, the most constraining factor for the participating respondents was lack of free time while the lack of variety of products was the strongest barrier for the non-participants. Generally, as per the hierarchical model, the nonparticipants felt more constrained by intrapersonal factors while the participants were most constrained by structural factors. This agrees with early scholars such as Gilbert and Hudson (2000) who argued that though both groups were constrained by structural factors in the form of economic issues and time, the non-participants faced more intrapersonal constraints. Consequently, participants and non-participants of domestic tourism should be treated as heterogeneous groups that require different strategies to enhance participation. Consequently, there is need to come up with distinct strategies to deal with structural constraints (lack of free time, income and inaccessible destinations) for current tourists and intrapersonal constraints (lack of personal transport, lack of travel culture and lack of knowledge on where to go) together with lack of product variety for the potential ones.

For the current tourists, the time constraint implies that domestic tourism offerings need to be designed to align to the available free time such as public, school and religious holidays, incentive packages during employee leave days, and weekends among others. Additionally, there is also a need to package the products in such a way that the needs of people with family 
commitments such as young children are met. This would be in response to the constraints on family commitments which were also strongly cited. Other key constraints for participants were lack of personal transport and inaccessible destinations. Thus, transport should be a key consideration when designing packages to cater for those without suitable transport. It is crucial to note that in some of the nature-based destinations, the vehicle needs to be a fourwheel-drive car hence eliminating the use of regular family cars which may not be able to access these destinations (Stone and Stone, 2017). While it may not always be possible to manipulate structural constraints, it is possible to design products that reduce the perception of being constrained (Hung and Petrick, 2012). This principle could be applied to the existing tourists by ensuring they get value for money and go away with a memorable experience. It is this experience that will guarantee repeat guests and increase participation despite the existence of constraints. Thus, strategies for existing tourists should be those that mitigate the structural constraints. This includes designing products that align with leisure time and guarantee value for money by creating memorable experiences.

The most constraining factor cited by the non-participating respondents was lack of variety in tourism activities. This implies that the current product offering as it stands does not meet the needs of the potential domestic tourist market that the industry seeks to harness. This correlated with lack of family-oriented activities which also came out strongly for this group. These findings support those of studies by (Kihima, 2015; Morupisi and Mokgalo, 2017; Ndivo et al., 2012; Okello et al., 2012; Stone and Stone, 2017; The National Department of Tourism South Africa, 2012; Wang and Chen, 2013). Thus, in order to lure the potential tourists, there is need to not only diversify the existing product offering but to ensure that it is tailored to meet the needs of the domestic market. This calls for continuous research on the product preferences for this group. Furthermore, it would be pragmatic to segment the market in order to facilitate optimal positioning of niche products that meet specific needs. Potential segments include families, social groups such as alumni associations and women groups, religious groups, educational institutions, corporate institutions, government, upcoming professionals, and retirees.

Besides lack of product variety, the most constraining intrapersonal constraints for the non-participants was lack of personal transport. This is in tandem with findings by Mutinda and Mayaka (2012), Magableh and Kharabsheh (2013), Kruger and Douglas (2015) and Stone and Stone (2017) who cited the same as a constraint to domestic tourism participation. As recommended for the existing tourist, stakeholders targeting potential tourists should treat transport as a key consideration when designing packages for this group. Lack of travel culture as postulated by Mazimhaka (2007), Manono and Rotich (2013), Morupisi and Mokgalo (2017) and Stone and Stone (2017) was also strongly cited as an intrapersonal constraint. This portends that travel culture and more significantly a saving culture for holidays should be instilled from an early age through avenues such as learning institutions and religious forums. Incentive travel at the workplace as part of staff motivation packages can also help to inculcate this culture. As postulated by Nyaupane and Andereck (2007), intrapersonal constraints require strategies geared towards attitude change which are not often captured by regular place marketing. Lack of knowledge of where to go was also cited as another major constraint as also posited by (Magableh and Kharabsheh, 2013; Mutinda and Mayaka, 2012; Mazimhaka ;2007). This could be mitigated by targeted marketing using the segments developed above. This would ensure that the marketing messages not only highlight the various destinations, niche products available but that they are also availed via various media suitable for specific niches. The implication of the above is that strategies for the potential tourists should focus on product diversification through a shift from mass tourism products to special interest tourism informed by research on domestic product preferences. The strategies should also be geared towards attitude change to counter intrapersonal constraints. 
The findings of this study are limited by various factors that may inform future research in domestic tourism. The study used quantitative methods hence missing out on the deeper nuances of constraints that would have been generated through a qualitative approach. Future studies should, therefore, incorporate qualitative approaches so as to gain in-depth meaning and also answer questions of how and why. The study was also limited to constraints captured by the hierarchical model of constraints. Future studies could either include other factors from other constraint models or develop other contemporary models. The other limitation of the study was the consideration of one independent variable. Since literature has shown that there could be other factors affecting domestic tourism participation behaviour such as motivation and demographic characteristics, future studies should incorporate these other variables besides constraints.

\section{References}

Alexandris, K., \& Carroll, B. (1997). An analysis of leisure constraints based on different recreational sport participation levels: Results from a study in Greece. Leisure Sciences, 19(1), 1-15. https://doi.org/10.1080/01490409709512236.

Blazey, M. A. (1987). The Differences Between Participants and Non-participants in a Senior Travel Program. Journal of Travel Research, 26(1), 7-12.

Buchanan, T., \& Allen, L. R. (1985). Barriers to recreation participation in later life cycle stages. Therapeutic Recreation Journal, 19(3), 39-50.

Cai, L. A., Hu, B., \& Feng, R. (2002). Domestic tourism demand in China's urban centres: Empirical analyses and marketing implications. Journal of Vacation Marketing, 8(1), 64-74. https://doi.org/10.1177/135676670200800107.

Chen, N., \& Funk, D. C.(2010). Exploring destination image, experience and revisit intention: kk A comparison of sport and non-sport tourist perceptions. Journal of Sport and Tourism, 15(3), 239-259. https://doi.org/10.1080/14775085.2010.513148.

County Government of Nairobi. (2014). Nairobi County Integrated Development Plan 20132018.

Crawford, D. W., \& Godbey, G. (1987). Reconceptualizing barriers to family leisure. Leisure Sciences, 9(2), 119-127.

Crawford,D.W.,Jackson,E.L., \& Godbey,G.(1991).A hierarchical model of leisure Constraint. Leisure Sciences, 13(4), 309-320.

Figueiredo, E., Eusébio, C., \& Kastenholz, E. (2012). How Diverse are Tourists with Disabilities? A Pilot Study on Accessible Leisure Tourism Experiences in Portugal. International Journal of Tourism Research, 14(6), 531-550.

Freeman, I., \& Selmi, N. (2009). French versus Canadian Tourism: Response to the Disabled. JournalofTravelResearch, 49(4), 471-485.

Funk, D. C., Alexandris, K., \& Ping, Y. (2009). To go or stay home and watch: exploring thebalance between motives and perceived constraints for major events: a case study of the 2008 Beijing Olympic Games. International Journal of Tourism Research, 11(1), 41-53.

Gassiot, A., Prats, L., \& Coromina, L. (2018). Tourism constraints for spanish tourists with disabilities: Scale development and validation. Documents d'Analisi Geografica, 64(1), 49-71. https://doi.org/10.5565/rev/dag.364.

Gilbert, D., \& Hudson, S. (2000). Tourism demand constraints: A skiing participation. Annals of Tourism Research, 27(4), 906-925. https://doi.org/10.1016/S0160-7383(99)00110-3

Goeldner, C. R., \& Ritchie, J. R. B. (2011). Tourism: Principles, Practices. (12 ${ }^{\text {th }}$ ed.). Wiley.

Government of Kenya. (2013). National Tourism Strategy 2013-2018.

Government of Kenya. (2018). Third Medium Term Paper 2018-2022. 
https://planning.go.ke/wp-content/uploads/2018/12/Third-Medium-Term-Plan-20182022.pdf.

Hinch, T, \& Higham, J. (2011). Sport tourism development (Aspects of Tourism 2 ed.). UnitedKingdom. Channel View Publications.

Hinch, Tom, Jackson, E. L., Hudson, S., \& Walker, G. (2005). Leisure constraint theory and sport tourism. Sport in Society, 8(2), 142-163.

Hua, K. P., Ibrahim, I., \& Chiu, L. K. (2013). Sport Tourism: Physically-Disabled Sport Tourists ' Orientation. Procedia - Social and Behavioural Sciences, 91(2004), 257-269. https://doi.org/10.1016/j.sbspro.2013.08.423.

Hubbard, J., \& Mannell, R. C. (2001). Testing Competing Models of the Leisure Constraint Negotiation Process in a Corporate Employee Recreation Setting. Leisure Sciences, 23(3), 145-163. https://doi.org/10.1080/014904001316896846.

Hung, K., \& Petrick, J. (2010). Developing a measurement scale for constraints to cruising. Annals of Tourism Research, 37 (1), 206-228. Annals of Tourism Research, 37, 206-228. https://doi.org/10.1016/j.annals.2009.09.002

Hung, K., \& Petrick, J. F. (2012). Comparing Constraints to Cruising Between Cruisers and Non-Cruisers: A Test of the Constraint-Effects-Mitigation Model. Journal of Travel \&Tourism Marketing, 29(3), 242-262. https://doi.org/10.1080/10548408.2012.666171

Jackson, E. L., Crawford, D. W., \& Godbey, G. (1993). Negotiation of leisure constraints. Leisure Sciences, 15(1), 1-11. https://doi.org/10.1080/01490409309513182

Jackson, E. L., \& Searle, M. S. (1985). Recreation non-participation and barriers to participation, concepts and models. Loisir et Société / Society and Leisure, 8(2), 693707. https://doi.org/10.1080/07053436.1985.10715236

Kattiyapornpong, U., \& Miller, K. (2009). Socio-demographic constraints to travel behaviour. International Journal of Culture, Tourism and Hospitality Research, 3(1), 81-94. https://doi.org/10.1108/17506180910940360

Kay, T., \& Jackson, G. (1991). Leisure despite constraint: The impact of leisure constraints on leisure participation. Journal of Leisure Research, 23(4), 301-313.

Kenya National Bureau of Statistics. (2019). Economic Survey 2019. https://www.theelephant.info/documents/kenya-national-bureau-of-statisticsconomicsurvey-2019/

Kerstetter, D. L., Zinn, H. C., Graefe, A. R., \& Chen, P.-J. (2002). Perceived Constraints to State Park Visitation: A Comparison of Former-Users and Non-Users. Journal of Park \& Recreation Administration, 20(1), 61-75.

Kihima, B. O. (2015). Domestic Tourism in Kenya: Trends, Initiatives and Practices. The East African Review, 50(May), 22-39. https://journals.openedition.org/eastafrica/289.

Korstanje, M. E. (2011). The fear of traveling: a new perspective for tourism and hospitality. Anatolia, 22(2), 222-233.

Kruger, E. A., \& Douglas, A. (2015). Constraints to consumption of South Africa's national parks among the emerging domestic tourism market. Development Southern Africa, 32(3), 303-319.

Lai, C., Li, X. (Robert), \& Harrill, R. (2013). Chinese outbound tourists' perceived constraints to visiting the United States. Tourism Management, 37, 136146.https://doi.org/https://doi.org/10.1016/j.tourman.2013.01.014

Lew, A. ., Hall, M. ., \& Timothy, D. (2008). World Geography of Travel and Tourism. A regional approach.Butterworth-Heinemann.United Kingdom.

Li, H., Meng, F., \& Zhang, Z. (2016). Non-participation of Domestic Tourism: Analyzing the Influence of Discouraging Factors. International Journal of Tourism Research, 18(6), 567-578. https://doi.org/10.1002/jtr.2074.

Li, H., Zhang, Z., \& Goh, C. (2015). Analyzing Non-Participation in Domestic Tourism: a Combined Framework. Journal of Travel \& Tourism Marketing, 32(4), 454-473. 
https://doi.org/10.1080/10548408.2014.908160.

Magableh, I. K., \& Kharabsheh, R. (2013). Antecedents of local demand for domestic tourism in Jordan. International Journal of Culture, Tourism and Hospitality Research, 7(1), 78-92. https://doi.org/10.1108/17506181311301372.

Manono, G., \& Rotich, D. (2013). Seasonality Effects on Trends of Domestic and International Tourism: A Case of Nairobi National Park , Kenya. 3(1), 131140.https://www.iiste.org/Journals/index.php/JNSR/article/view/4202/4255.

Mazimhaka, J. (2007). Diversifying Rwanda's tourism industry: A role for domestic tourism. Development Southern Africa, 24(3), 491-504. https://doi.org/10.1080/03768350701445590.

McGuire, F. A. (1983). Constraints on Leisure Involvement in the Later Years. Activities Adaptation \& Aging, 3(2), 17-24. https://doi.org/10.1300/J016v03n02_05.

Morupisi, P., \& Mokgalo, L. (2017). Domestic tourism challenges in Botswana: A stakeholders' perspective. Cogent Social Sciences, 3(1). https://doi.org/10.1080/23311886.2017.1298171.

Mugenda, O., \& Mugenda, A. (2003). Research Methods-Qualitative and Quantitative approaches. In African center for technology studies.

Mutinda, R., \& Mayaka, M. (2012). Application of destination choice model: Factors influencing domestic tourists destination choice among residents of Nairobi, Kenya. Tourism Management, 33(6), 1593-1597.

Nadirova, A., \& Jackson, E. L. (2000). Alternative Criterion Variables Against Which to Assess the Impacts of Constraints to Leisure. Journal of Leisure Research, 32(4), 396-405. https://doi.org/10.1080/00222216.2000.11949923.

Ndivo, R. ., Waudo, J. ., \& Waswa, F. (2012). Examining Kenya's tourist destination's appeal: the perspectives of domestic tourism market. Journal of Tourism \& Hospitality, 01(05), 1-7. https://doi.org/10.4172/2167-0269.1000103.

Nyaupane, G. P., \& Andereck, K. L. (2007). Understanding Travel Constraints: Application and Extension of a Leisure Constraints Model. Journal of Travel Research, 46(4), 433-439. https://doi.org/10.1177/0047287507308325.

Nyaupane, G. P., Morais, D. B., \& Graefe, A. R. (2004). Nature Tourism Constraints: A Cross-Activity Comparison. Annals of Tourism Research, 31(3), 540-555. https://doi.org/https://doi.org/10.1016/j.annals.2004.01.006.

Okello, M., Kenana, L., \& Kieti, D. (2012). Factors influencing domestic tourism for urban and semiurban populations around Nairobi National Park, Kenya. Tourism Analysis, 17(1), 79-89. https://doi.org/10.3727/108354212X13330406124214.

Okello, M., \& Novelli, M. (2014). Tourism in the East African Community (EAC): Challenges, opportunities, and ways forward. Tourism and Hospitality Research, 14(2), 53-66. https://doi.org/10.1177/1467358414529580.

Park, S. Y., \& Petrick, J. F. (2009). Examining current non-customers: A cruise vacation case. Journal of Vacation Marketing, 15(3), 275-293.

Pennington-Gray, L., \& Kerstetter, D. (2002). Testing a Constraints Model within the Context of Nature-Based Tourism. Journal of Travel Research, 40, 416423.https://doi.org/10.1177/0047287502040004008.

Peterson, M., \& Lambert, S. L. (2015). A Demographic Perspective on us Consumers' Outof-Town Vacationing and Commercial Lodging Usage While on Vacation. In Creating and Delivering Value in Marketing (p. 27). Springer.

Pivac, T. (2012). Wine tourism of Vojvodina. In Scientific-Mathematical Faculty, University of Novi Sad, Department for geography, tourism and hotel management, Novi Sad.

Pizam, A., \& Fleischer, A. (2002). Severity versus Frequency of Acts of Terrorism: Which Has a Larger Impact on Tourism Demand? Journal of Travel Research, 40(3), 337339. 
Poria, Y., Biran, A., \& Reichel, A. (2009). Visitors' Preferences for Interpretation at Heritage Sites. Journal of Travel Research, 48(1), 92-105.

Scheyvens, R. (2007). Poor cousins no more: valuing the development potential of domesticand diaspora tourism. Progress in Development Studies, 7(4), 307325.https://doi.org/10.1177/146499340700700403.

Schneider, I. E., Schroeder, S. L., \& Schwaller, A. (2011). Structural constraints to wilderness: impacts on visitation and experience. International Journal of Wilderness.17 (1): 14-21., 14-21.

Stone, L. S., \& Stone, T. M. (2017). Domestic Tourism In Botswana: An Examination Of Nature - Based Tourism Constraints. Botswana Journal of Business, 10(1).

Thapa, B. (2012). Why did they not visit? Examining structural constraints to visit Kafue National Park, Zambia. Journal of Ecotourism, 11(1), 74-83.

The National Department of Tourism, South Africa. (2012). Domestic Tourism Growth Strategy2012-2020(p.15).https://www.tourism.gov.za/AboutNDT/Branches1/ domestic/ Documents/Domestic Tourism Growth Strategy 2012-2020.pdf

Tian, S., Crompton, J. L., \& Witt, P. A. (1996). Integrating Constraints and Benefits to Identify Responsive Target Markets for Museum Attractions. Journal of Travel Research, 35(2), 34-45. https://doi.org/10.1177/004728759603500207.

Tourism Research Institute. (2018). Tourism sector 2018. 1-6. http://www.tri.go.ke/.

UNWTO. (2018). UNWTO Tourism Highlights. International Tourism Trends 2017. 1-20. https://doi.org/https://doi.org/10.18111/9789284419876.

UNWTO. (2019). International Tourism Highlights 2019. https://doi.org/https://www.eunwto.org/doi/pdf/10.18111/9789284421152?download=true.

Veal, A. J. (2017). Research methods for leisure and tourism. Pearson UK.

Wang, D., \& Chen, T. (2013). Temporal-spatial change and driving mechanism for regional difference of domestic tourism in China. Chinese Journal of Population Resources and Environment, 11(1), 69-78. https://doi.org/10.1080/10042857.2013.777525.

World Travel Tourism Council. (2019). Domestic tourism importance and economic impact. In World Travel \& Tourism Council. https://www.wttc.org/publications/2018/domestic-tourism/

\section{Author Biography}

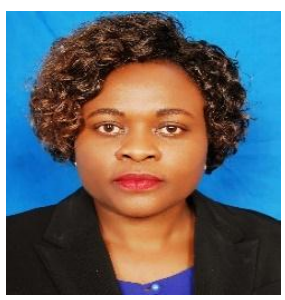

Catherine Kifworo is a tourism management graduate from Moi University, holder of MA Project Planning Management from University of Nairobi, Kenya and a PhD student in Tourism Management from Moi University, Kenya. Catherine is a member of faculty at the school of Tourism, Hospitality and Leisure Management, Maasai Mara University. She is also a certified Monitoring and Evaluation Specialist. 


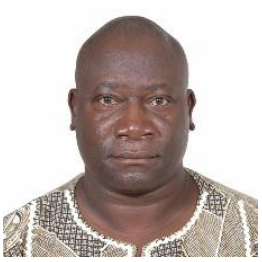

Prof. Moses Okello has extensive teaching and research experience in wildlife management and ecology, Human -wildlife interactions, resource use and ecotourism. He holds a B.Sc. degree in Wildlife Management from Moi University; M.Sc. in Wildlife Resources from the University of Idaho and his Ph.D. in Wildlife Management and Ecology from the University of Alberta. He has worked at Moi University and at the School for Field Studies (SFS) Centre for Wildlife Management Studies (CWMS) where he rose from a lecturer to a full professor. $\mathrm{He}$ is widely published and is also currently the Centre Director of SFS Centre in Kenya.

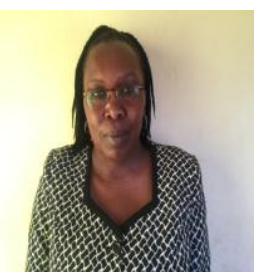

Isabella Mulemia Cheloti-Mapelu is a Senior Lecturer in the School of Tourism, Hospitality, and Events Management at Moi University. She has successfully supervised three PhD and fourteen Masters theses and is an external examiner in one local University. She has authored two books, eight articles and twenty-one conference papers. She has also held various administrative roles including being the Founding Chair of the School Graduate Studies Committee and head of department for Hospitality. She has also participated actively in the development and implementation of curricula for Undergraduate, Masters and Doctor of Philosophy (PhD) in the area of Hospitality. 